\title{
Ocena poziomu jakości życia chorych na hemofilię*
}

\section{The evaluation of the quality of life in patients with haemophilia}

\author{
Joanna Owsianowska ${ }^{凶}$ \\ Pomorski Uniwersytet Medyczny w Szczecinie, Zakład Pielęgniarstwa, ul Żołnierska 48, 71-210 Szczecin \\ $\triangle$ jowsian@pum.edu.pl
}

\begin{abstract}
Introduction: Haemophilia is a genetic disease. Bleeding, pain, temporary or long-term lack of physical activity, and even the risk of disability could have a negative impact on the quality of life. The aim of the paper is to evaluate the quality of life of patients with haemophilia, and to provide answers to the following questions: 1 . What is the quality of life of patients with haemophilia? 2. Which sphere of life is given the highest and which is given the lowest score? 3. Is there a connection between the sociodemographic data, the health situation and the quality of life?

Materials and methods: In total 163 adults diagnosed with haemophilia who are mainly treated at home and living in different parts of Poland were included in the survey. All sociodemographic data were collected using an author-designed questionnaire. The quality of life was measured using the WHOQOL-100 questionnaire proposed by World Health Organization.

Results: All surveyed patients were males diagnosed with haemophilia A, which is consistent with the epidemiology of the disease and the fact that haemophilia $A$ is more frequent in Poland than haemophilia B. Most of the males (144) were diagnosed
\end{abstract}

with severe haemophilia, 18 with moderate and only 6 with mild haemophilia. What is more, $126(75 \%)$ respondents had type C hepatitis.

Conclusions: In the field of 6 life spheres measured with the use of the WHOQOL-100 questionnaire the highest score - 14.66was gained in the sphere of spirituality, religion and personal beliefs. The lowest score - 12.99 - was gained in the physical sphere, mostly concerning pain and feelings of discomfort. The outcome of 12.89 was gained in the environmental sphere. After detailed analysis of the researched material there was a conclusion made: 1 . A group of men with inborn haemophilia demonstrate an average quality of life, comparable to the level of life of sick people living in other European countries. 2. The researched group give the highest estimate to the spiritual sphere of life, religion and personal beliefs, while the physical and environmental spheres were given the lowest estimate. 3. The degree of seriousness of haemophilia is of core importance when it comes to the level of life. Type $\mathrm{C}$ hepatitis and the status of pensioner is also a serious matter.

Keywords: haemophilia; disability; quality of life.

\begin{abstract}
ABSTRAKT
Wstęp: Hemofilia należy do chorób uwarunkowanych genetycznie. Występowanie krwawień, doznawanie bólu, okresowe lub trwałe zmniejszenie aktywności fizycznej czy wreszcie ryzyko wystąpienia kalectwa mogą wywierać negatywny wpływ na wielowymiarowe funkcjonowanie człowieka.

Celem pracy było poznanie poziomu jakości życia chorych na hemofilię oraz udzielenie odpowiedzi na następujące pytania badawcze: 1. Jaki poziom jakości życia prezentują chorzy na hemofilię? 2. Która dziedzina jakości życia oceniana jest przez chorych na hemofilię najwyżej, a która najniżej? 3.Czy istnieje związek pomiędzy danymi socjodemograficznymi i sytuacją zdrowotną a jakością życia i jej dziedzinami?

Materiały i metody: Badaniami objęto 168 dorosłych pacjentów chorujących na hemofilię, pozostających głównie w systemie leczenia domowego i zamieszkujących różne regiony Polski. Dane socjodemograficzne zebrano za pomocą ankiety własnego autorstwa, natomiast do pomiaru jakości życia zastosowano zaproponowany przez Światową Organizację Zdrowia kwestionariusz WHOQOL-10o służący do oceny sytuacji życiowej pacjentów będącej konsekwencją choroby i stosowanej terapii.
\end{abstract}

Wyniki: Wszyscy badani chorzy byli płci męskiej i chorowali na hemofilię $\mathrm{A}$, co jest zgodne zarówno $\mathrm{z}$ epidemiologią schorzenia, jak i z faktem, iż hemofilia A występuje w Polsce znacznie częściej niż hemofilia B. Najliczniejszą grupę (144 mężczyzn) stanowili pacjenci z ciężką postacią choroby, najmniej liczną ze stopniem lekkim (6 osób), natomiast stopień umiarkowany choroby występował u 18 badanych. Trzy czwarte (126 osób) miało wirusowe zapalenie wątroby typu C. W zakresie 6 dziedzin jakości życia zmierzonych za pomocą kwestionariusza WHOQOL-100 najwyższy wynik 14,66 uzyskano w dziedzinie duchowości, religii i osobistych przekonań, natomiast najniższy w dziedzinie fizycznej 12,99, zwłaszcza w podskali mierzącej ból i dyskomfort oraz dziedzinie środowiskowej 12,89.

Wnioski: 1. Badana grupa mężczyzn z wrodzoną hemofilią wykazuje średni poziom jakości życia, porównywalny z jakością życia chorych z innych krajów europejskich. 2. Badana grupa chorych najwyżej ocenia dziedzinę związaną z duchowością, religią i osobistymi przekonaniami, natomiast najniżej dziedzinę fizyczną i środowiskową. 3. Na istotne obniżenie globalnej jakości życia wpływa ciężki stopień choroby, wirusowe zapalenie wątroby typu C oraz status rencisty.

Słowa kluczowe: hemofilia; niepełnosprawność; jakość życia. 


\section{WSTĘP}

Hemofilia A i B są wrodzonymi skazami krwotocznymi spowodowanymi zmniejszeniem w osoczu aktywności odpowiednio czynnika krzepnięcia krwi VIII (hemofilia A) lub czynnika krzepnięcia krwi IX (hemofilia B) [1]. Podobnie jak wszystkie inne cechy zależne od genów, które są sprzężone z chromosomem X, zarówno hemofilia A, jak i B pojawia się głównie u mężczyzn, natomiast kobieta, która przekazuje cechę, jest jej nosicielką. Aktywność czynnika VIII lub IX w osoczu nosicielek wynosi najczęściej ok. 50\% wartości prawidłowych, co jest wystarczające do zabezpieczenia funkcjonowania wtórnej hemostazy i sprawia, że u nosicielek rzadko dochodzi do nadmiernych krwawień [2]. Skłonność do krwawień może natomiast wystąpić u kobiet, które zostały dotknięte skrajną lionizacją, to znaczy nieprawidłową inaktywacją chromosomu X [2, 3]. Znaczny odsetek kobiet będących nosicielkami hemofilii ma niski poziom stężenia czynnika VIII lub IX w osoczu, który oscyluje w dolnych granicach normy, a niekiedy stwierdza się jego znaczne obniżenie. Wiąże się to ze zwiększoną skłonnością do krwawień lub z występowaniem objawów charakterystycznych dla łagodnych postaci choroby $[2,4,5]$. Z danych Instytutu Hematologii i Transfuzjologii wynika, że w Polsce jest 2216 osób z hemofilią A i 389 osób z hemofilią B. Liczby te obejmują łącznie wszystkie grupy wiekowe [6].

U chorych na hemofilię hemostaza pierwotna przebiega w sposób prawidłowy. Jednak utworzony płytkowy czop hemostatyczny nie zostaje dostatecznie wzmocniony przez włóknik, ponieważ następstwem niedoboru czynnika VIII lub IX jest wytwarzanie zbyt małej ilości trombiny, która przekształca fibrynogen w fibrynę. Słaba struktura skrzepu szybko i łatwo ulega rozpadowi, w efekcie czego dochodzi do nadmiernych krwawień typu opóźnionego. Zarówno hemofilia A, jak i hemofilia B nie różnią się pod względem przebiegu klinicznego, a różnicowanie opiera się na podstawie badań oznaczających aktywność czynnika VIII bądź IX w osoczu [1, 2, 3, 4].

Intensywność krwawienia w hemofilii zależy od stężenia w osoczu czynnika VIII bądź IX. Wyróżnić można trzy postacie choroby: ciężką, w której aktywność czynnika VIII lub IX wynosi <0,01 j.m./mL ( $<1 \%$ normy); umiarkowaną - 0,01-0,05 j.m./mL (1-5\% normy); łagodną od $>0,05$ do $<0,50$ j.m. $/ \mathrm{mL}$ (od $>5$ do $<50 \%$ normy) [3, 7, 8].

Podział ten jest niezwykle przydatny ze względu na korelację z objawami skazy. Głównym objawem ciężkiej postaci choroby są samoistne wylewy krwi do stawów. Zwykle zaczynają się one pojawiać ok. 2.-3. r.ż., a najczęstszym umiejscowieniem są stawy kolanowe, łokciowe i skokowo-goleniowe [3, 4]. Występujące często krwawienia do stawów przyczyniają się do ich postępującego zwyrodnienia. Krwawienie może być także umiejscowione w mięśniach, dnie jamy ustnej, tylnej ścianie gardła czy jamach ciała. Krwawienia śródczaszkowe i krwawienia z przewodu pokarmowego należą do najgroźniejszych objawów hemofilii. Stosunkowo często obserwowany jest krwiomocz. Krwawienia, które są następstwem urazów, wypadków, ekstrakcji zębów czy zabiegów operacyjnych przeprowadzonych bez osłony hemostatycznej, należą do typowych objawów [3, 4, 5, 7]. W postaci umiarkowanej krwawienia do mięśni i stawów występują po zadziałaniu niewielkiego urazu, natomiast nadmierne krwawienie jest następstwem urazu, wypadku, ekstrakcji zęba czy zabiegu chirurgicznego. Postać łagodna choroby charakteryzuje się występowaniem nadmiernych krwawień po urazach, ekstrakcjach zębów, wypadkach i zabiegach chirurgicznych [3, 5, 9].

Wynikiem powtarzających się krwawień, głównie do dużych stawów, jak stawy kolanowe, łokciowe czy skokowe, jest artropatia hemofilowa [10, 11]. Podstawową obecnie metodą leczenia choroby jest zwiększanie aktywności niedoborowego czynnika krzepnięcia w krwiobiegu w celu zahamowania aktywnego krwawienia lub też jego prewencji. Zarówno w profilaktyce, jak i w leczeniu krwawień u pacjentów z hemofilią stosuje się liofilizowane koncentraty czynnika VIII lub czynnika IX osoczopochodne, rekombinowane i desmopresynę. Zastosowanie mają także leki hamujące fibrynolizę $[3,10,12]$.

Wysokie koszty leczenia są przyczyną występowanie nierówności w dostępie do opieki na świecie [3, 5, 12, 13, 14]. Głównym celem postępowania z chorymi na ciężką postać choroby jest jak najbardziej efektywne zapobieganie samoistnym krwawieniom zarówno do mięśni, jak i stawów, prewencja krwawień w okresie okołooperacyjnym oraz skuteczne zwalczanie epizodów krwotocznych. Optymalna opieka wymaga zatem dokładnej diagnozy, doświadczenia w prowadzeniu, stosowania profilaktyki od najmłodszych lat, aby zapobiegać krwawieniom i nie dopuścić do wystąpienia artropatii oraz - a może przede wszystkim - odpowiedniej ilości bezpiecznych produktów terapeutycznych. Najpoważniejszym powikłaniem substytucyjnego leczenia ciężkiej postaci hemofilii jest wytworzenie alloprzeciwciał przeciwko czynnikowi VIII lub IX. Ryzyko rozwoju przeciwciał jest większe u pacjentów z ciężką postacią hemofilii A i wynosi ok. 30-50\%, natomiast u pacjentów $\mathrm{z}$ ciężką postacią hemofilii B przeciwciała rozwijają się u ok. 1,5-3\%. Przeciwciała zwane inhibitorami hamują aktywność czynnika krzepnięcia VIII lub IX [13, 15, 16, 17].

Każdy pacjent $\mathrm{z}$ hemofilią powinien być monitorowany pod względem ryzyka rozwoju inhibitora. Rozpoznanie częstości występowania inhibitora oraz regularne monitorowanie jego miana jest mierzone w teście Bethesda, z modyfikacją Nijmegen $[18,19]$. Wyeliminowanie inhibitora u pacjentów $\mathrm{z}$ hemofilią to główny cel leczenia, ponieważ umożliwia substytucję z użyciem standardowych koncentratów krzepnięcia krwi. Prawidłową hemostazę można osiągnąć u pacjentów z inhibitorami o niskim mianie $(\leq 5 \mathrm{j}$.B. $/ \mathrm{mL})$ za pomocą wysokich dawek niedoborowego czynnika, jednak u pacjentów o mianie wysokim (>5 j.B./mL) należy stosować preparaty zawierające aktywowane czynniki krzepnięcia [20]. Dostępne obecnie dane wskazują, że aktywowane preparaty omijające inhibitor są bezpieczne i skuteczne w kontrolowaniu krwawień u chorych na hemofilię z inhibitorami. Nie zmienia to jednak faktu, że należy dążyć do eliminacji inhibitora poprzez stosowanie indukcji tolerancji immunologicznej [21]. Od ponad 30 lat moźliwe jest leczenie chorych na hemofilię w warunkach domowych, a nie w szpitalu. Takie rozwiązanie jest korzystne ekonomicznie i poprawia 
jakość życia osoby chorej oraz jej rodziny. Przy stosowaniu tego typu terapii leczenie można wdrożyć natychmiast po rozpoczęciu krwawienia, co zmniejsza ilość potrzebnego środka leczniczego, skraca krótkoterminową niepełnosprawność, zmniejsza długotrwałe uszkodzenie stawów i przyczynia się do zachowania niezależności funkcjonalnej. Sprawą o dużym znaczeniu jest prowadzenie praktycznych programów edukacyjnych dla pacjentów i ich rodzin dotyczących odpowiedniego stosowania czynnika krzepnięcia, szukania natychmiastowej pomocy w sytuacji wystąpienia istotnych krwawień czy braku skuteczności leczenia [19].

Jakość życia jest pojęciem wielowymiarowym, które obejmuje wiele aspektów życia. Jest odzwierciedleniem poglądów przedstawicieli filozofii, socjologii, psychologii i medycyny [22]. Badania jakości życia oraz analizowanie otrzymanych wyników przyczyniają się do opracowywania nowych, skutecznych metod leczenia, wraz z oceną ich efektywności, a także do podejmowania działań zarówno profilaktycznych, rehabilitacyjnych, jak i psychoterapeutycznych, które łagodzą negatywne skutki chorób [23, 24].

Celem pracy było poznanie poziomu jakości życia chorych na hemofilię oraz udzielenie odpowiedzi na następujące pytania badawcze: 1. Jaki poziom życia prezentują chorzy na hemofilię? 2. Która dziedzina jakości życia oceniana jest przez chorych na hemofilię najwyżej, a która najniżej? 3. Czy istnieje związek pomiędzy danymi socjodemograficznymi i sytuacją zdrowotną a jakością życia i jej dziedzinami?

\section{MATERIAŁY I METODY}

Badaniami objęto 168 chorych na hemofilię A z całego kraju, w wieku od 18 do ponad 60 lat. Byli to pacjenci objęci głównie systemem leczenia domowego, zamieszkujący różne regiony Polski. Za kryterium włączenia do badania uznano: dorosły wiek, hemofilię, zgodę na udział w badaniu.

Sondaż diagnostyczny przeprowadzony został za pomocą kwestionariusza ankiety własnej konstrukcji obejmującego sytuację socjodemograficzną i zdrowotną.

Do pomiaru jakości życia zastosowano zaproponowany przez Światową Organizację Zdrowia kwestionariusz WHOQOL-100 służący do oceny sytuacji życiowej pacjentów, będącej konsekwencją choroby i stosowanej terapii. Kwestionariuszem badane jest 6 dziedzin, na które składają się 24 podskale oraz jedna podskala ogólna oceniająca globalną jakość życia i percepcję ogólnego stanu zdrowia. Wynik liczbowy z 6 dziedzin jakości życia odpowiada indywidualnej jakości życia w każdej z tych dziedzin. Wartości odpowiedzi, po przeliczeniu zgodnie z przyjętym w instrukcji WHOQOL-100 algorytmem, mieszczą się w zakresie 4-20. Wynik liczbowy zarówno globalnej jakości życia i percepcji ogólnego stanu zdrowia, jak i 6 dziedzin jakości oraz 21 podskal ma kierunek pozytywny, tzn. większej wartości odpowiada lepsza jakość życia. Wyjątek stanowią 3 podskale, w przypadku których wartości liczbowe mają kierunek malejący (negatywny): Ból i dyskomfort, Negatywne uczucia oraz Zależność od leczenia i leków. Badanie dotyczy dziedzin życia: 1) fizycznej, 2) psychologicznej, 3) poziomu niezależności, 4) relacji społecznych, 5) środowiskowej, 6) duchowości/religii/osobistych przekonań.

Analizę statystyczną zebranego materiału przeprowadzono z użyciem pakietu Statistica 10.o PL (StatSoft, Polska). W prezentacji wyników w przypadku zmiennych ilościowych wykorzystano metody statystyki opisowej, jak: średnia arytmetyczna, odchylenie standardowe, minimum, maksimum, mediana. W odniesieniu do zmiennych jakościowych zastosowano liczebność i procent. Analizę istotności różnic pomiędzy wartościami średnimi w porównywanych grupach przeprowadzono przy zachowaniu obowiązujących zasad doboru testów statystycznych. W tym celu oceniono rozkład badanych zmiennych ilościowych za pomocą testu Shapiro-Wilka i Kołmogorowa-Smirnowa, a następnie sprawdzono równości wariancji grupowych testem Levene’a. Ponieważ większość analizowanych zmiennych nie spełniła warunków, przy weryfikacji hipotez wykorzystano testy nieparametryczne. Do oceny istotności różnic pomiędzy dwiema grupami zastosowano test U Manna-Whitneya. Analizę różnic pomiędzy wartościami średnimi dla trzech i więcej porównywanych grup przeprowadzono za pomocą wariancji H Kruskala-Wallisa i odpowiednimi testami post-hoc. Do określenia istotności różnic pomiędzy porównywanymi grupami w odniesieniu do zmiennych jakościowych wykorzystano tabele krzyżowe i test $\chi^{2}$.

We wszystkich analizach jako istotne przyjęto efekty, dla których wartość prawdopodobieństwa p była mniejsza od przyjętego poziomu istotności 0,05 $(\mathrm{p}<0,05)$.

\section{WYNIKI}

Wszyscy spośród 168 badanych pacjentów chorowali na hemofilię A. W przypadku 144 (85,71\%) mężczyzn była to postać ciężka. Postać umiarkowaną miało 18 (10,71\%) osób, natomiast tylko $6(3,57 \%)$ respondentów przyznało, że choruje na łagodną postać choroby. W mieście zamieszkiwało 132 $(78,57 \%)$ badanych, a tylko $36(21,43 \%)$ mężczyzn było mieszkańcami wsi. Większość ankietowanych - 48 (28,57\%) badanych - stanowili chorzy poniżej 35. r.ż. Najmniej liczną grupą $18(10,71 \%)$ badanych - byli pacjenci między 26. a 35. r.ż. Grupę respondentów powyżej 59. r.ż. tworzyło 30 (17,86\%) osób, tylu badanych należało do przedziału wiekowego 36.-45. r.ż. Studia wyższe ukończyło 60 (35,71\%) badanych, 78 (46,43\%) miało wykształcenie średnie, natomiast 18 (10,71\%) zasadnicze zawodowe. Głównym źródłem utrzymania w badanej grupie była renta - 132 (78,57\%) badanych. Spośród tej liczby osób dodatkowo $60(35,71 \%)$ chorych oprócz renty podejmowało pracę zawodową. Wyłącznie z wynagrodzenia za pracę utrzymywało się zaledwie 18 spośród 168 (10,71\%) ankietowanych, natomiast $6(3,57 \%)$ respondentów nie miało żadnego źródła dochodu. Były to osoby z ciężką postacią choroby, należące do najmłodszego przedziału wiekowego 18.-25. r.ż., z wykształceniem średnim. Spośród badanej grupy 168 pacjentów najwięcej było kawalerów - 78 (46,43\%). Żonatych było 66 (39,29\%) osób, natomiast rozwiedzionych 24 (14,29\%). 
Trzy czwarte spośród grupy badanych (126 osób) chorowało na wirusowe zapalenie wątroby typu C (WZW C), z czego 53 $(42,06 \%)$ respondentów nie zostało poddanych leczeniu. Spośród $73(43,45 \%)$ chorych poddanych leczeniu przeciwwirusowemu leczenie z powodzeniem zakończyło 49 (38,89\%) osób, w chwili badania w trakcie leczenia pozostawało 18 (14,29\%), natomiast terapia okazała się nieskuteczna dla 6 (4,76\%) osób.

W zakresie globalnej jakości życia i ogólnego stanu zdrowia badani pacjenci uzyskali średni wynik 13,04 (SD = 3,44). Minimalna wartość, jaką uzyskano, wynosiła 5, a maksymalna 18. W aspekcie globalnej jakości życia i ogólnego stanu zdrowia wyższy wynik oznacza lepszą jakość życia, dlatego podczas analizy wyników badanej grupy zaobserwowano średni poziom jakości życia pacjentów z hemofilią (tab. 1).

TABELA 1. Wskaźnik jakości życia wg WHOQOL-100

\begin{tabular}{lcccccc} 
Skala WHOQOL-100 & $\mathbf{n}$ & $\bar{x}$ & Me & Min. & Maks. & SD \\
\hline $\begin{array}{l}\text { Globalna jakość życia } \\
\text { i ogólny stan zdrowia }\end{array}$ & 168 & 13,04 & 13,00 & 5,00 & 18,0 & 3,44 \\
\hline
\end{tabular}

n - liczebność; $\bar{x}$ - średnia arytmetyczna; Me - mediana; Min. - minimum; Maks. maksimum; SD - odchylenie standardowe

W zakresie 6 dziedzin jakości życia mierzonych za pomocą kwestionariusza WHOQOL-100 najwyższy średni wynik - 14,36 (SD = 3,04) uzyskano w zakresie dziedziny duchowości/religii/ osobistych przekonań (tab. 2). Następnie 13,46 (SD = 2,21) uzyskano w dziedzinie relacji społecznych. W zakresie dziedziny dotyczącej poziomu niezależności uzyskano średni wynik $13,22(\mathrm{SD}=2,10)$, natomiast w zakresie dziedziny psychologicznej - 13,06 (SD = 1,10). Najmniejszą liczbę punktów uzyskano w dziedzinach fizycznej - 12,99 (SD = 2,10) i środowiskowej$12,89(\mathrm{SD}=0,76)$.

TABELA 2. Poszczególne dziedziny jakości życia wg WHOQOL-100

\begin{tabular}{lcccccc}
$\begin{array}{c}\text { Dziedziny jakości życia } \\
\text { WHOQOL-100 }\end{array}$ & $\mathbf{n}$ & $\bar{x}$ & Me & Min. & Maks. & SD \\
\hline Fizyczna & 168 & 12,99 & 13,67 & 7,00 & 16,0 & 2,10 \\
\hline Psychologiczna & 168 & 13,06 & 13,10 & 11,20 & 14,8 & 1,10 \\
\hline Poziom niezależności & 168 & 13,22 & 13,25 & 9,00 & 17,5 & 2,10 \\
\hline Relacje społeczne & 168 & 13,46 & 13,67 & 8,00 & 17,7 & 2,21 \\
\hline Środowiskowa & 168 & 12,89 & 12,94 & 11,25 & 15,0 & 0,76 \\
\hline $\begin{array}{l}\text { Duchowość/religia/ } \\
\text { osobiste przekonania }\end{array}$ & 168 & 14,36 & 15,00 & 5,00 & 20,0 & 3,04
\end{tabular}

n - liczebność; $\bar{x}$ - średnia arytmetyczna; Me - mediana; Min. - minimum; Maks. maksimum; SD - odchylenie standardowe

Dziedzina duchowości/religii/osobistych przekonań jakości życia w skali WHOQOL-100 obejmuje podskalę o tej samej nazwie i wartości punktowe - 14,36 (SD =3,04).

Dziedzina fizyczna jakości życia w skali WHOQOL-100 jest składową 3 podskal, gdzie najwyższe wartości uzyskano w zakresie energii i zmęczenia - 13,57 (SD =1,98). Najniższe wartości, a tym samym niską jakość życia zaobserwowano w podskali mierzącej ból i dyskomfort - 10,89 $(\mathrm{SD}=4,03)$.

Dziedzina środowiskowa jakości życia w skali WHOQOL-100 stanowi składową 8 podskal, spośród których najwyższą wartość liczbową - 14,95 (SD = 2,61) uzyskano w zakresie podskali obejmującej możliwości uzyskiwania nowych informacji i umiejętności. Najniższą wartość - 10,74 (SD = 1,98) otrzymano w zakresie opieki zdrowotnej i społecznej: dostępność i jakość.

Spośród ankietowanych najwyższą wartość punktową 17,00, wyrażającą globalną jakość życia i ogólny stan zdrowia, uzyskali pacjenci mający łagodny stopień ciężkości hemofilii. Najmniej punktów - 12,43 mieli pacjenci z ciężkim stopniem hemofilii. Analiza wykazała istnienie zależności statystycznej pomiędzy stopniem ciężkości choroby a globalną jakością życia i ogólnym stanem zdrowia $(\mathrm{p}=0,0000)$. Zaobserwowano istotne statystycznie różnice w wynikach pomiędzy pacjentami z ciężkim stopniem choroby a pacjentami z łagodnym $(\mathrm{p}=0,0007)$ oraz umiarkowanym $(\mathrm{p}=0,0000)$ stopniem ciężkości hemofilii (ryc. 1).



RYCINA 1. Globalna jakość życia i ogólny stan zdrowia względem stopnia ciężkości hemofilii w grupie badanych

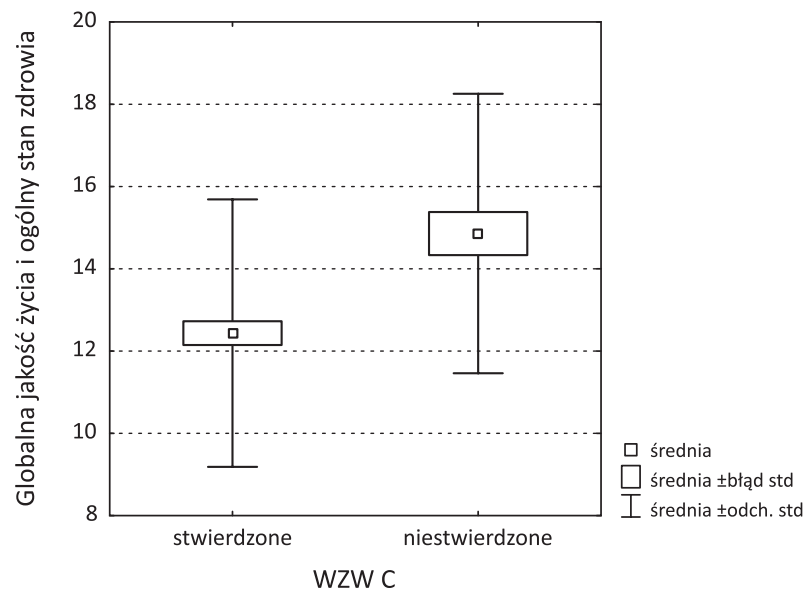

RYCINA 2. Globalna jakość życia i ogólny stan zdrowia względem stwierdzonego wirusowego zapalenia wątroby typu C (WZW C) w grupie badanych

Spośród ankietowanych wyższą wartość punktową - 14,85 wyrażającą globalną jakość życia i ogólny stan zdrowia uzyskali pacjenci, u których nie stwierdzono obecności WZW C (ryc. 2). Mniej punktów - 12,43 uzyskali pacjenci ze stwierdzoną obecnością WZW C. Analiza wykazała istnienie zależności statystycznej pomiędzy obecnością WZW C a globalną jakością życia i ogólnym stanem zdrowia $(p=0,0000)$. Zaobserwowano 
istotne statystycznie różnice w wynikach pomiędzy pacjentami z WZW C a pacjentami bez WZW C $(p=0,0000)$.

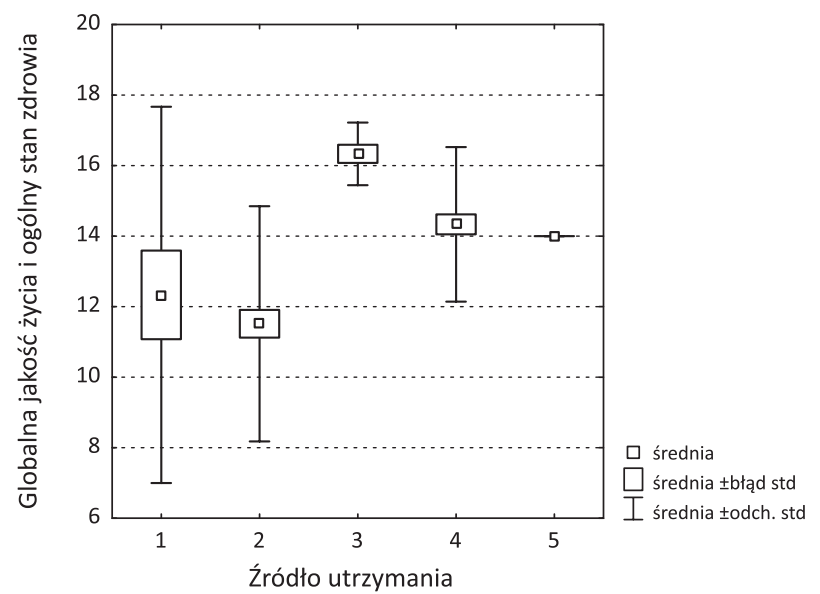

1 - wynagrodzenie za pracę zawodową; 2 - renta; 3 - emerytura; 4 - renta i praca zawodowa; 5 - brak wynagrodzenia

RYCINA 3. Globalna jakość życia i ogólny stan zdrowia względem źródła utrzymania badanych

Spośród ankietowanych najwyższą wartość punktową 16,33, wyrażającą globalną jakość życia i ogólny stan zdrowia, uzyskali badani, dla których źródłem utrzymania są świadczenia emerytalne (ryc. 3). Najmniej punktów - 11,51 uzyskali pacjenci utrzymujący się z renty. Analiza wykazała istnienie zależności statystycznej pomiędzy źródłem utrzymania a globalną jakością życia i ogólnym stanem zdrowia ( $p=0,0000)$. Zaobserwowano istotne statystycznie różnice w wynikach pomiędzy pacjentami utrzymującymi się ze świadczeń rentowych a pacjentami utrzymującymi się ze świadczeń emertytalnych $(p=0,0000)$ oraz pacjentami utrzymującymi się zarówno $\mathrm{z}$ renty, jak i pracy zawodowej $(\mathrm{p}=0,0001)$.

\section{DYSKUSJA}

Hemofilia jest chorobą przewlekłą, która może wywierać negatywny wpływ na jakość życia związaną ze zdrowiem. Stan ten może być spowodowany objawami choroby, jak: występowanie krwawień, doznawanie uczucia bólu, zmniejszenie aktywności fizycznej, występowanie kalectwa, co z kolei może wywierać niekorzystny wpływ na osiąganie wyników w nauce, pracy, kontaktach społecznych, życiu rodzinnym czy zaburzać wypoczynek.

Wszyscy badani chorzy byli płci męskiej, co jest zgodne z epidemiologią schorzenia i co jednocześnie potwierdzają Jończyk i wsp. [25], Aznar i wsp. [26], Varaklioti i wsp. [27], von Mackensen i wsp. [28], a także Wojna i wsp. [29]. Wszyscy badani chorowali na hemofilię A, co jest zgodne $\mathrm{z}$ faktem jej częstszego występowania niż hemofilia B [6].

Ponieważ w badaniach własnych założono, że istnieje związek między sytuacją socjodemograficzną a sytuacją zdrowotną, które mogą wywierać istotny wpływ na jakość życia w tej grupie chorych, dlatego zapytano o kilka kwestii związanych z tymi aspektami. Na pytanie dotyczące stanu cywilnego 39,29\% badanych udzieliło odpowiedzi, iż pozostaje w związku małżeńskim, 46,43\% zakwalifikowało siebie do grupy kawalerów, a 14,29\% badanych osób określiło swój status jako rozwiedziony. Zbliżony wynik uzyskali Jończyk i wsp. W ich badaniu połowa spośród 40 osób była stanu wolnego, natomiast pozostałe w związkach małżeńskich [25]. Również w badaniach przeprowadzanych przez Varaklioti i wsp. na 118 pacjentach z hemofilią A i B 61\% było stanu wolnego [27]. Rozkład wykształcenia i miejsce zamieszkania w badanej grupie wyglądały podobnie jak w badaniach Jończyk i wsp., gdzie wykształcenie wyższe deklarowało 40\% ankietowanych, natomiast wykształcenie średnie ponad połowa badanych. W aglomeracjach miejskich żyje ponad połowa respondentów [25]. Są to więc wyniki zbieżne z uzyskanymi, gdzie wyższe wykształcenie deklaruje $35,71 \%$ badanych, a średnie $46,43 \%$, status mieszkańca aglomeracji miejskiej ma 78,57\% osób. W badaniach przeprowadzonych przez Varaklioti i wsp. również przeszło połowa pacjentów zamieszkiwała w dużej aglomeracji miejskiej, jednak aż 57,6\% osób nie ukończyło nawet szkoły średniej [27].

Bardzo ważnym problemem związanym z egzystencją człowieka jest możliwość wykonywania pracy zawodowej, która jest źródłem utrzymania, zapewnia możliwość uporządkowanego, celowego zajęcia i jest miejscem, w którym człowiek nawiązuje relacje społeczne. Spośród badanych pacjentów aż 42,86\% pozostaje na rencie, a tylko 10,71\% pracuje zawodowo, chociaż dodatkowe zarobkowanie oprócz renty podejmuje $35,71 \%$ respondentów. $Z$ badań przeprowadzonych przez innych autorów wynika, że pracy zawodowej nie podejmuje ok. 30-50\% pacjentów, głównie z ciężką postacią hemofilii [25, 27].

Analizie poddano również ciężkość skazy krwotocznej. Stwierdzono, że $85,71 \%$ badanych choruje na ciężką postać choroby z poziomem czynnika krzepnięcia krwi poniżej $1 \%$. Pozostałe osoby $(10,71 \%)$ obciążone były umiarkowaną postacią choroby, natomiast lekką postać miało tylko 3,57\%. Ten stan rzeczy potwierdzają również badania innych autorów, w których największy odsetek pacjentów stanowią chorzy $\mathrm{z}$ ciężką postacią choroby $[25,26,27,30]$.

Jednym z najpoważniejszych powikłań leczenia preparatami krwiopochodnymi jest występowanie wirusowych zakażeń przenoszonych drogą krwi. Produkcja koncentratów czynników krzepnięcia krwi na skalę przemysłową z dużej puli osocza pochodzącego od wielu tysięcy dawców stwarzała wysokie ryzyko zakażenia tymi właśnie wirusami. W latach 70. i 80. XX w. znaczna część pacjentów została zarażona wirusem zapalenia wątroby typu C, a w niektórych krajach również wirusem HIV [6, 31]. Z przeprowadzonych badań wynika, że 75\% respondentów jest zakażonych WZW C, natomiast ani jedna osoba nie jest nosicielem wirusa HIV. Podobny odsetek chorych z WZW C $(71,2 \%)$ zaobserwowali Varaklioti i wsp., jednak u tych autorów również $28 \%$ respondentów było nosicielami wirusa HIV [27]. Badania Jończyk i wsp. są również potwierdzeniem tego problemu - zakażenie WZW C stwierdzono u 66\% respondentów, natomiast nie stwierdzono nosicielstwa wirusa HIV [25]. W badaniach von Mackensena i wsp. 
przeprowadzonych na 39 pacjentach chorujących na hemofilię A i B i należących do populacji osób starszych stwierdzono także częstsze występowanie przewlekłych chorób wirusowych przenoszonych drogą krwi w grupie osób chorych w porównaniu z grupą kontrolną [28].

Khawaji i wsp. [32] oraz Lindvall i wsp. [33] zajmujący się problematyką hemofilii, zaobserwowali, że wcześniejsze rozpoczęcie profilaktyki wpływa korzystnie na jakość życia, zwłaszcza w dziedzinie fizycznej i relacji społecznych. Późniejsze badanie Khawaji i wsp. przeprowadzone na dużej grupie pacjentów z ciężką postacią hemofilii A i B jest potwierdzeniem tego stanu rzeczy, ponieważ chorzy, którzy rozpoczęli stosowanie profilaktyki w wieku 3 lat lub poniżej, lepiej funkcjonowali w sferze fizycznej w porównaniu z grupą, która profilaktykę rozpoczęła po ukończeniu 3. r.ż. [34]. Plug i wsp. w trakcie badania pacjentów zwrócili uwagę na fakt, iż osoby, które urodziły się po wprowadzeniu profilaktyki, wykazują wyższy poziom w dziedzinie fizycznej niż osoby urodzone przed wprowadzeniem profilaktyki [35]. W przeprowadzonych badaniach własnych uzyskano rozbieżności wiekowe dotyczące rozmieszczenia punktów z dziedziny fizycznej, jednak najwyższa wartość punktowa w grupie chorych między 26.-35. r.ż. może być potwierdzeniem tego, iż osoby, które były leczone w sposób bardziej nowoczesny i konsekwentny od najwcześniejszych lat, wykazują wyższy poziom w tej właśnie dziedzinie.

Jończyk i wsp., badając jakość życia chorych na hemofilię, zastosowali kwestionariusz WHOQOL-BREF autorstwa Jaracz i Wołowickiej składający się z 26 pytań, które umożliwiają ocenę jakości życia w 4 dziedzinach: fizycznej, psychologicznej, społecznej i środowiskowej. Dziedzina fizyczna uzyskała liczbę punktów zbliżoną do dziedziny psychologicznej i środowiskowej, której przyznano najmniej punktów, natomiast zdecydowanie największą liczbę punktów uzyskała dziedzina społeczna, co zdaniem badaczy świadczy o bardzo dobrych relacjach zarówno osobistych, jak i społecznych tej grupy chorych [25]. W badaniach własnych za pomocą pełnej wersji kwestionariusza (WHOQOL-100) otrzymano zbliżone wyniki; zdecydowanie najmniejszą liczbę punktów uzyskano w dziedzinie fizycznej i środowiskowej, natomiast najwyższą w zakresie dziedziny dotyczącej duchowości. Dziedzina relacji społecznych zajmuje miejsce drugie ze średnim wynikiem 13,46. Również w badaniach przeprowadzonych we Włoszech przez Kodra i wsp. ponad 75\% ankietowanych miała problemy w sferze fizycznej, szczególnie w zakresie mobilności i doznawania dolegliwości bólowych [36]. Carvalhosa i wsp. w badaniu pacjentów z hemofilią A i hemofilią B posłużyli się skalą SF 36, która stanowi ogólną miarę jakości życia osób dorosłych. Również w wyniku tych badań zauważono, że ankietowani uzyskiwali niskie wyniki w sferze fizycznej, a obecność objawów artropatii miała istotne konsekwencje dla jakości życia nie tylko w dziedzinie fizycznej, ale także funkcjonowania społecznego [37]. Następną rozpatrywaną dziedziną jest dziedzina psychologiczna, na którą składają się następujące podskalne: pozytywne uczucia, negatywne uczucia, myślenie - uczenie się - pamięć, koncentracja, samoocena, wygląd zewnętrzny.
Według Jończyk i wsp. dziedzina psychologiczna jest stosunkowo nisko oceniana przez chorych na hemofilię i zajmuje miejsce równorzędne z dziedziną fizyczną [25]. Również badania von Mackensena i wsp. przeprowadzane za pomocą kwestionariusza WHOQOL-BREF pokazują niską punktację w zakresie podskal, które wchodzą w skład dziedziny psychologicznej [28]. Potwierdzeniem tego są wyniki uzyskane z badań własnych, wg których dziedzina ta została tylko niewiele lepiej oceniona od stosukowo nisko punktowanej dziedziny fizycznej, a najniższą wartość 11,92 uzyskano w zakresie podskali odczuwania negatywnych uczuć.

Szaniawska-Thiel i Laguna uważają, że większość społeczeństw przypisuje mężczyznom cechy takie, jak: niezależność, przywództwo, agresywność. Autorki sugerują, że w tak zawężonym postrzeganiu roli mężczyzny nie ma miejsca dla osoby, która zmaga się z chorobą przewlekłą. Ponadto widoczność pewnych symptomów choroby, jak deformacje w stawach czy zaniki mięśniowe, należy brać pod uwagę, gdy rozważa się udzielanie pomocy psychologicznej. Bardzo istotnym momentem związanym z rozwojem człowieka, w którym psychologiczne wsparcie wydaje się być szczególnie istotne, jest okres dorastania pacjentów chorujących na hemofilię [38].

Badacze tacy jak Iannone i wsp. uważają, że pacjenci z hemofilią muszą radzić sobie z wieloma zagrożeniami i zaburzeniami funkcjonalnymi, w związku z czym badanie czynników ryzyka wystąpienia depresji jest sprawą niezmiernie ważną, a może nawet kluczową w udzieleniu wsparcia i poprawie psychicznego samopoczucia [39].

Trzecią dziedziną, z której składa się globalna jakość życia, jest poziom niezależności, na który składają się podskale: mobilność, czynności życia codziennego, zależność od leków lub leczenia, zdolność do pracy lub nauki. Wszystkie dostępne obecnie dane wskazują, że nawet dotknięty ciężką postacią hemofilii pacjent ma szansę na prowadzenie normalnego trybu życia, w tym na zachowanie pełnej aktywności zawodowej, bez konieczności korzystania ze świadczeń przysługujących z tytułu niepełnosprawności [40, 41].

Wojna i wsp. przebadali 22 chłopców w wieku 6-14 lat z różnym stopniem ciężkości hemofilii A, aby ocenić wpływ kompleksowego postępowania fizjoterapeutycznego na stan czynnościowy stawów kolanowych i łokciowych, a także na jakość życia tej grupy chorych. Badania te wykazały, że proponowana metoda leczenia wpłynęła korzystnie na zmianę trybu życia pacjentów. Nastąpiła duża poprawa w zakresie mobilności, mniej konieczne stało się korzystanie z pomocy opiekunów w trakcie wykonywania czynności dnia codziennego czy korzystanie z nauczania indywidualnego w warunkach domowych. Autorzy wysnuli zatem wniosek, że zastosowanie terapii substytucyjnej niedoborowego czynnika krzepnięcia w połączeniu z fizjoterapią wywiera dodatni wpływ na poprawę stanu czynnościowego stawów, co z kolei umożliwia chorym na hemofilię A poprawę jakości życia [29]. Jończyk i wsp. stwierdzili, że istnieje związek pomiędzy aktywnością zawodową i posiadaniem czynnika krzepnięcia krwi w domu, czyli prowadzeniem tzw. leczenia domowego a jakością życia pacjentów z hemofilią A. Na tej podstawie autorzy dowiedli, 
iż do najważniejszych czynników mających wpływ na jakość życia w tej grupie chorych należy zarówno posiadanie czynnika krzepnięcia krwi w domu, jak i zachowanie aktywności zawodowej [25]. Podobne wyniki uzyskano w badaniach własnych, gdzie najwyższą wartość punktową w globalnej jakości życia uzyskali pacjenci mający czynnik krzepnięcia w domu i podający go sobie w razie konieczności. Natomiast w podskali poziomu niezależności największą wartość punktową uzyskali pacjenci, którzy nie otrzymują czynnika krzepnięcia do domu, a najmniejszą z kolei posiadający czynnik krzepnięcia w domu i podający go sobie w sytuacjach koniecznych. Niewątpliwie sytuacja ta ma związek ze stopniem ciężkości choroby, czego dowodem jest fakt, iż spośród ankietowanych najwyższą wartość punktową w dziedzinie wyrażającej poziom niezależności uzyskali pacjenci z łagodnym stopniem ciężkości hemofilii, a osoby z ciężkim stopniem uzyskały najmniej punktów. Analiza wykazała również istnienie zależności statystycznej pomiędzy stopniem ciężkości choroby a poziomem niezależności badanych $(\mathrm{p}=0,0000)$. Należy podkreślić również, że na poziom niezależności składa się także podskala obejmująca zależność od leków i leczenia. Można przypuszczać, że pacjenci, zwłaszcza z ciężką postacią hemofilii, gdzie poziom niedoborowego czynnika krzepnięcia jest niższy niż $1 \%$ normy, wymagają prowadzenia kompleksowej terapii przez całe życie i mogą w związku z tym odczuwać dużą zależność od procesu leczenia.

Kolejną dziedziną rozpatrywaną w trakcie badania jakości życia pacjentów z hemofilią jest ta, którą określa się mianem relacji społecznych. Na relacje społeczne składają się podskale: relacje społeczne, wsparcie społeczne i aktywność seksualna. W badaniach własnych dziedzina ta uzyskała drugi co do wielkości wynik w rozkładzie poszczególnych dziedzin, które mierzy WHOQOL-100. Najwyższą wartość liczbową uzyskano w podskali relacji społecznych, natomiast najniższą w podskali dotyczącej aktywności seksualnej. Podobny wynik dotyczący relacji uzyskali w swoich badaniach Jończyk i wsp., gdzie dziedzinie społecznej przypadło zdecydowanie najwięcej punktów, jednak w badaniach tych nie wykryto związku pomiędzy tą dziedziną a jakością życia badanych [25].

Dune twierdzi, że brak jest zarówno doświadczenia klinicznego, jak i badań empirycznych na temat seksualności i hemofilii, co utrudnia świadczenie holistycznej opieki zdrowotnej. Autor ten uważa, iż na stosunki seksualne u pacjentów z hemofilią mogą wpływać różnego rodzaju ograniczenia fizyczne, dlatego też należy przeprowadzać więcej badań klinicznych i empirycznych w celu zwrócenia uwagi na związek hemofilii z seksualnością. Seksualność jest bardzo ważnym aspektem życia człowieka i wywiera istotny wpływ na funkcjonowanie nie tylko w wymiarze biologicznym, ale także psychologicznym i społecznym [42]. Podobne podejście prezentuje Parish, który uważa, że seksualność jest bardzo ważnym wymiarem życia każdego człowieka, niemniej jednak istnieje ciągły niedostatek literatury dotyczącej seksualności i choroby przewlekłej. Poczucie własnej wartości człowieka jest nierozerwalnie związane z możliwością osiągania celów i znalezieniem sensu w życiu. W przypadku seksualności poczucie własnej wartości umożliwia odczuwanie fizycznej atrakcyjności i pożądania. Interakcja ta jest jednak szczególnie trudna wówczas, gdy człowiek zmagający się z chorobą przewlekłą żyje w kulturze, która ceni głównie zdrowe i silne jednostki, idealizując trudno osiągalne doskonałości w wyglądzie fizycznym. Seksualność obejmuje zatem cały szereg aspektów, które mogą być wyrażane i doświadczane na wielu poziomach i różnorodnymi sposobami. Mogą one zarówno wpływać, jak i pozostawać pod wpływem fizycznych, psychologicznych, społecznych oraz kulturowych wyznaczników, zajmując ważne miejsce w kompleksowej opiece nad pacjentem z hemofilią [43].

Badania von Mackensena i wsp. dotyczące populacji osób chorych na hemofilię w wieku podeszłym wykazały, że pacjenci z wysokim ryzykiem upadku wykazują gorsze funkcjonowanie zarówno w dziedzinie fizycznej, jak i środowiskowej w zakresie podskali dotyczącej czasu wolnego: uczestnictwa i możliwości rekreacji [28]. Podsumowując rozważania dotyczące relacji społecznych pacjentów chorujących na hemofilię, należy zwrócić uwagę na fakt, iż najniższą wartość punktową w tej dziedzinie uzyskali pacjenci z ciężką postacią choroby, najwyższą natomiast osoby ze stopniem umiarkowanym. Analiza badań własnych wykazała istnienie zależności statystycznej pomiędzy stopniem ciężkości choroby a globalną jakością życia i ogólnym stanem zdrowia ( $\mathrm{p}=0,0000)$.

Dziedzina określana jako środowiskowa jest składową 8 podskal, jak: bezpieczeństwo, środowisko domowe, finanse, opieka zdrowotna i społeczna (dostępność i jakość), możliwość uzyskania nowych informacji i umiejętności, czas wolny (uczestnictwo i możliwość rekreacji), środowisko fizyczne (zanieczyszczenia, hałas, ruch uliczny, klimat).

W badaniach Jończyk i wsp. dziedzinie środowiskowej przyznano najmniej punktów, natomiast największe niedociągnięcia dotyczyły poczucia bezpieczeństwa w życiu, miejsca zamieszkania, zasobów finansowych, dostępności do opieki zdrowotnej i możliwości przemieszczania się [25]. Podobny wynik uzyskano w badaniach własnych, gdzie dziedzina określana jako środowiskowa uzyskała najmniejszą liczbę punktów $(12,89)$. Najniższą wartość uzyskano podobnie jak w badaniach Jończyk i wsp. [25] w zakresie opieki zdrowotnej i społecznej: dostępności i jakości.

Kolejna rozpatrywana dziedzina to duchowość, religia i osobiste przekonania, która w skali WHOQOL-100 obejmuje tylko jedną podskalę o tej samej nazwie. W przeprowadzonych badaniach własnych dziedzina ta otrzymała najwyższy średni wynik - 14,36. Ponadto analiza wykazała istnienie zależności statystycznej pomiędzy duchowością, religią, osobistymi przekonaniami a wiekiem, wykształceniem, źródłem utrzymania, stanem cywilnym, stopniem ciężkości choroby, możliwością podawania sobie czynnika krzepnięcia oraz przebytymi zabiegami operacyjnymi. Trudno jest porównać wyniki badań własnych, ponieważ w literaturze przedmiotu nie ma szerszych opisów wyników badań. Być może inni badacze uznali ją za dziedzinę mało ważną w swoich obserwacjach jakości życia chorych na hemofilię. Tylko w badaniu Jończyk 
i wsp. wykazano istnienie zależności statystycznej pomiędzy aktywnością zawodową a dziedziną psychologiczną, do której dołączone są pytania dotyczące duchowości, religii i osobistej wiary [25].

Wprowadzenie w Polsce programu profilaktyki pierwotnej w $2008 \mathrm{r}$. powinno istotnie wpłynąć na poprawę jakości życia, a tym samym celowe jest powtórzenie tego badania w przyszłości w grupach pacjentów poddanych profilaktyce.

\section{WNIOSKI}

1. Badana grupa mężczyzn z wrodzoną hemofilią wykazuje średni poziom jakości życia, porównywalny z jakością życia chorych w innych krajach europejskich.

2. Badana grupa chorych najwyżej ocenia dziedzinę związaną z duchowością, religią i osobistymi przekonaniami, natomiast najniżej dziedzinę fizyczną i środowiskową.

3. Na istotne obniżenie globalnej jakości życia wpływa ciężki stopień choroby, wirusowe zapalenie wątroby typu C oraz status rencisty.

\section{PIŚMIENNICTWO}

1. White GC, Rosendaal F, Aledort LM, Luster JM, Rothschild C, Ingerslev J. Definitions in haemophilia. Recommendations of the Scientific Subcommittee on Factor VIII and Factor IX of the Scientific and Standarization Committee of the International Society on Thrombosis and Haemostasis. Thromb Haemost 2001;85(3):560.

2. Plug J, Mauser-Bunschoten EP, Bröcker-Vriends AH, van Amstel HK, van der Bom JG, van Diemen-Homan JE, et al. Bleeding in carriers of hemophilia. Blood 2006;108(1):52-6. doi: 10.1182/blood-2005-09-3879.

3. Windyga J. Hemofilie - postępy w diagnostyce i leczeniu. Acta Haematol Pol 2010;41(2):183-99.

4. Windyga J. Skazy krwotoczne. Warszawa: PZWL; 2006. p. 70-7.

5. Bolton-Maggs PH. Optimal haemophilia care versus the reality. Br J Haematol 2006;132(6):671-82. doi: 10.1111/j.1365-2141.2005.05952.x.

6. Narodowy Program Leczenia Chorych na Hemofilię i Pokrewne Skazy Krwotoczne na lata 2012-2018. http://www.mz.gov.pl/wp-content/ uploads/2015/06/aktualizacjascalona-hemofilia-program-24.02.17dpz-do-podpisu-na-czysto.pdf (5.05.2016).

7. Łopaciuk S. Zaburzenia krzepnięcia krwi. In: Dmoszyńska A, Robak T, editors. Podstawy hematologii. Lublin: Czelej; 2003. p. 373-82.

8. Amador-Medina LF, Vargas-Ruiz AG. Hemophilia. Rev Med Inst Mex Seguro Soc 2013;51(6):638-43.

9. Mannuccio Mannucci P, Franchini M. Present and future challenges in the treatment of haemophilia: a clinician's perspective. Blood Transfus 2013;11 Suppl 4:77-81. doi: 10.2450/2013.012s.

10. Amstermark J, Dolan G, Hilberg T, Jimenéz-Yuste V, Laffan M, Lassila R, et al. Managing haemophilia for life: 4 th haemophilia global summit. Haemophilia 2014;20 Suppl 5:1-20. doi: 10.1111/hae.12468.

11. Stephensen D, Drechsler WI, Scott OM. Biomechanics of lower limb haemophilic arthropathy. Blood Rev 2012;26(5):213-21. doi: 10.1016/j. blre.2012.06.003.

12. Windyga J. Jak w przyszłości będziemy leczyć hemofilię? Acta Haematol Pol 2008;39(4):651-60.

13. Batorova A, High KA, Gringeri A. Special lectures in haemophilia management. Haemophilia 2010;16 Suppl 5:22-8. doi: 10.1111/j.13652516.2010.02289.x.

14. Zimmermann R, Staritz P, Huth-Kühne A. Challenges in treating elderly patients with haemophilia: a focus on cardiology. Thromb Res 2014;134 Suppl 1:48-52. doi: 10.1016/j.thromres.2013.10.023.
15. Franchini M, Frattini F, Crestani S, Bonfanti C. Haemophilia B: current pharmacotherapy and future directions. Expert Opin Pharmacother 2012;13(14):2053-63. doi: 10.1517/14656566.2012.721780.

16. Markusic DM, Hoffman BE, Perrin GQ, Nayak S, Wang X, LoDuca PA, et al. Effective gene therapy for haemophilic mice with pathogenic factor IX antibodies. EMBO Mol Med 2013;5(11):1698-709. doi: 10.1002/ emmm.201302859.

17. Windyga J. Profilaktyka krwawień u chorych na hemofilię A powikłaną inhibitorem czynnika VIII. Hematologia 2011;2(4):311-7.

18. Astermark J, Morado M, Rocino A, van den Berg HM, von Depka M, Gringeri A, et al. Current European practice in immune tolerance induction therapy in patients with haemophilia and inhibitors. Haemophilia 2006;12(4):363-71. doi: 10.1111/j.1365-2516.2006.01296.x.

19. Colvin BT, Astermark J, Fischer K, Gringeri A, Lassila R, Schramm W, et al. European principles of haemophilia care. Haemophilia 2008;14(2):36174. doi: 10.1111/j.1365-2516.2007.01625.x.

20. Astermark J, Rocino A, von Depka M, Van Den Berg HM, Gringeri A, Montovani LG, et al. Current use of by-passing agents in Europe in the management of acute bleeds in patients with haemophilia and inhibitors. Haemophilia 2007;13(1):38-45. doi: 10.1111/j.1365-2516.2006.01403.x.

21. Franchini M, Mannucci PM. Haemophilia A in the third millennium. Blood Rev 2013;27(4):179-84. doi: 10.1016/j.blre.2013.06.002.

22. Jaracz K. Jakość życia po niedokrwiennym udarze mózgu: uwarunkowania kliniczne, funkcjonalne, psychospołeczne i czasowe. Poznań: Katedra Pielęgniarstwa Akademii Medycznej im. Karola Marcinkowskiego w Poznaniu; 2002.

23. Hudak PL, Wright JG. The characteristics of patient satisfaction measures. Spine 2000;25(24):3167-77.

24. Hunt SM, McKenna SP. Quality of life claims in trials of anti-hypertensive therapy. Qual Life Res 1997;6(2):185-91.

25. Jończyk H, Reczek A, Brzostek T, Zdziarska J. Jakość życia chorych na hemofilię typu A. Probl Pielęg 2009;17(2):116-22.

26. Aznar JA, Garcia-Dasi M, Pérez-Alenda S, Marco A, Jaca M, Moret A, et al. Secondary prophylaxis vs. on-demand treatment to improve quality of life in severe adult haemophilia. A patients: a prospective study in a single centre. Vox Sang 2014;106(1):68-74. doi: 10.1111/vox.12066.

27. Varaklioti A, Kontodimopolus N, Katsarou O, Niakas D. Psychometric properties of the greek Haem-A-QoL for measuring quality of life in Greek haemophilia patients. Biomed Res Int 2014;2014:968081. doi: 10.1155/2014/968081.

28. von Mackensen S, Gringeri A, Siboni SM, Mannucci PM. Italian Of Haemophilia Centres (AICE). Haemophilia 2012;18(3):345-52.

29. Wojna D, Anwajler J, Mlądzka I, Ostrowska B, Skolimowski T. Wpływ fizjoterapii na stan czynnościowy stawów łokciowych oraz jakość życia chorych na hemofilię. Ortop Traumatol Rehabil 2008;3(6):315-22.

30. Pollmann H, Klamroth R, Vidovic N, Kriukov AY, Epstein J, Abraham I, et al. Prophylaxis and quality of life in patients with haemophilia A during routine treatment with ADVATE [antyhemofilac factor (recombinant), plasma/albumin-free method] in Germany: a subgroup analysis of the ADVATE PASS post-approval, non-interventional study. Ann Hematol 2013;92(5):689-98. doi: 10.1007/s00277-013-1678-4.

31. World Federation of Haemophilia. Report on the Annual Global Survey 2012. http;//www1.wfh.org/publications/files/pdf (6.11.2014).

32. Khawaji M, Astermark J, von Mackensen S, Akesson K, Berntorp E. Bone density and health-related quality of life in adult patients with severe haemophilia. Haemophilia 2011;17(2):304-11. doi: 10.1111/j.13652516.2010.02423.x.

33. Lindvall K, von Mackensen S, Berntrop E. Quality of life in adult patients with haemophilia - a single centre experience from Sweden. Haemophilia 2012;18(4):527-31. doi: 10.1111/j.1365-2516.2012.02765.x.

34. Khawaji M, Astermark J, Berntorp E. Life long prophylaxis in a large cohort of adult patients with severe haemophilia: a beneficial on orthopaedic outcome and quality of life. Eur J Haematol 2012;88(4):329-35. doi: 10.1111/j.1600-0609.2012.01750.x.

35. Plug I, Paters M, Mauser-Bunschoten EP, de Goede-Bolder A, Heijnen L, Smit C, et al. Social participation of patients with haemophilia in the Netherlands. Blood 2008;111(4):1811-15. doi: 10.1182/blood-2007-07-102202.

36. Kodra Y, Cavazza M, Schippati A, De Santis M, Armeni P, Arcieri R, et al. The social burden and quality of life of patients with haemophilia in Italy. Blood Transfus 2014;12 Suppl 3:567-75. doi: 10.2450/2014.0042-14s. 
37. Carvalhosa AM, Henrard S, Lambert C, Hermans C. Physical and mental quality of life in adult patients with haemophilia in Belgium: the impact of financial issues. Haemophilia 2014;20(4):479-485. doi: 10.1111/hae.12341.

38. Szaniawska-Thiel M, Laguna P. 0 potrzebie pomocy psychologicznej dziecku choremu na hemofilię i jego rodzinie. Psychiatr Pol 2007;41(6):813-25.

39. Iannone M, Pennick L, Tom A, Cui H, Gilbert M, Weihs K, et al. Prevalence of depression in adults with Haemophilia. Haemophilia 2012;18(6):86874. doi: 10.1111/j.1365-2516.2012.02863.x.

40. Farrugia A, Cassar J, Kimber MC, Bansal M, Fischer K, Auserswald G, et al. Treatment for life for severe haemophilia A - A cost-utility model for prophylaxis vs. on-demand treatment. Haemophilia 2013;19(4):228-38. doi: $10.1111 /$ hae.12121.

41. Fischer K, Hermans C. The European Principles of Haemophilia Care: a pilot investigation of adherence to the principles in Europe. Haemophilia 2013;19(1):35-43. doi: 10.1111/j.1365-2516.2012.02928.x.

42. Dune T. Sexual expression, fulfilment and haemophilia: reflections from the 16th Australian and New Zealand Haemophilia Conference. Haemophilia 2012;18(3):138-9. doi: 10.1111/j.1365-2516.2011.02743.x.

43. Parish KL. Sexuality and haemophilia: connections across the life - span. Haemophilia 2002;8(3):353-9. 